\title{
Preparation and in vitro studies of fixed-dose tablet combination of repaglinide and metformin
}

\author{
Sinem Șahin' (D), Burcu Mesut² (D), M. Ezgi Durgun² (i), Esher Özçelik³ (D), Yıldız Özsoy² (1) \\ 'Onko Koçsel Pharmaceuticals, Kocaeli, Turkey \\ 2Istanbul University, Faculty of Pharmacy, Pharmaceutical Technology Department, Istanbul, Turkey \\ ${ }^{3}$ Cibali Health and Social Security Center, Istanbul, Turkey
}

ORCID IDs of the authors: S.Ș. 0000-0002-0377-2757; B.M. 0000-0003-2838-1688; M.E.D. 0000-0001-5724-9809;

E.Ö. 0000-0002-5611-1143; Y.Ö. 0000-0002-9110-3704

Cite this article as: Sahin, S., Mesut, B., Durgun, M.E., Ozcelik, E., \& Ozsoy, Y. (2021). Preparation and in vitro studies of fixed-dose tablet combination of repaglinide and metformin. Istanbul Journal of Pharmacy, 51 (1), 26-34.

\begin{abstract}
Background and Aims: The study aimed to design a Fixed-dose tablet formulation of Metformine and Repaglinide. Methods: Wet granulation method was used to prepare tablet formulations. Characterization studies and dissolution studies were performed.

Results: A stable formulation was developed according to the requirements of the pharmacopoeia criteria. This new formulsation dissolution results showed that Repaglinide and Metformin $\mathrm{HCl}$ dissolved more than $85 \%$ from film tablets at 15 minutes.

Conclusion: Thus, an alternative product to the market product was developed.

Keywords: Fixed-Dose Tablet, Metformin, Repaglinide
\end{abstract}

\section{INTRODUCTION}

Life expectancy is an average statistical data that indicates how long a newborn will live, assuming that death rates remain constant from the moment it is born. It is rapidly increasing worldwide thanks to factors such as the advancement of technology, development in new and effective treatment methods, improving the quality of care services, and facilitating individuals' access to care services. Since individuals' daily lives are directly affected by the socioeconomic status of the society they live in and the living standards offered by that country, life expectancy is calculated specifically for each country. The life expectancy of western countries is higher all around the world. As life expectancy increases, the prevalence of non-communicable chronic diseases (NCDs) such as cardiovascular, metabolic, and respiratory diseases may increase. Also, the changes in eating habits and the spread of fast-food-style nutrition throughout the world and the widespread of a sedentary lifestyle have a negative effect on individuals' metabolism. Thus, the diseases that are expected to be seen in the elderly population can be encountered at a younger age, even in the adolescent period.

Diabetes Mellitus (DM) is a metabolic disorder that causes hyperglycemia with impaired insulin production and/or function (Maffi \& Secchi, 2017; Spampinato, Caruso, De Pasquale, Sortino, \& Merlo, 2020). The American Diabetes Association (ADA) classified DM into two primary classes, types 1 and 2 (American Diabetes Association, 2015). In type 1 diabetes, insulin insufficiency occurs due to the destruction of the $\beta$-cells of the pancreas, where insulin is secreted. Type 2 diabetes is characterized by insulin resistance due to progressive insulin secretion defects. Type 2 DM usually occurs concerning age (Longo et al., 2019). A rapid 
increase in its prevalence was observed with prolonged life expectancy. The World Health Organization (WHO) reported that more than 425 million people worldwide live with diabetes, and more than 1.6 million deaths are directly related to diabetes (Rachdaoui, 2020; World Health Organization, 2020). Also, contrary to popular belief, Type 2 DM can be seen during childhood and adolescence (American Diabetes Association, 2000). Obesity, mainly due to changes in dietary and lifestyle habits, increased the prevalence of type 2 DM among children as well as adults. DM may destroy the vascular and neurological system due to hyperglycemia (Malone, 2016). Thus, different cases of NCDs are also seen in DM patients who cannot be treated efficiently. Problems in controlling the DM and accompanying other diseases seriously reduce the quality of life of the patient and his/her family and increase the costs of hospitalization (Riddle \& Herman, 2018; Young-Hyman et al., 2016). One of the approaches developed in the treatment of Type $2 \mathrm{DM}$ is to combine drugs to eliminate all the problems (Massi-Benedetti \& Orsini-Federici, 2008)

Combine drug therapy is the combined usage of active pharmaceutical ingredient (API) that has successful results with different action mechanisms in the treatment of a single disease. If a more effective and/or faster treatment process is desired, combined therapy can be preferred. Studies have shown that combined therapy with additional APIs in the treatment of chronic diseases is five times effective than increasing the dose of the drug used in single therapy by two times (Tsioufis \& Thomopoulos, 2017). In cases where hyperglycemia can not be controlled in type 2 DM patients with a single treatment agent, combined therapy is started (Massi-Benedetti \& Orsini-Federici, 2008). Considering the damage caused by hyperglycemia on the vascular and neural system, the combined treatment approach seems to be a clinical requirement rather than an option. Despite these significant advantages, combine treatment has two main disadvantages. One of these disadvantages is since the increasing number of drugs that the patient will take in one time, the patient's compliance may decrease. Increasing health care costs is the other one. To overcome this situation, fixed-dose combinations (FDCs) have been developed. FDCs are pharmaceutical dosage forms prepared by combining two or more APIs in a single formulation (Gautam \& Saha, 2008; Godman, McCabe, \& D Leong, 2020; Tangalos \& Zarowitz, 2005). Owing to FDCs, patient compliance may increase as it will use fewer drugs at one time and achieve a more therapeutic effect. Also, since the therapeutic effect will be increased, the dose of each APIs can be reduced. Thus systemic side effects can be reduced.

Metformin, a biguanide drug, is a first option in the treatment of type 2 DM patients who cannot be controlled with lifestyle changes (Lefèbvre \& Scheen, 1992; Sanchez-Rangel \& Inzucchi, 2017). It is used safely in Europe since 1957 and in America since 1995 (Pernicova \& Korbonits, 2014). It increases the effect of insulin in the liver and decreases hepatic glucose production (Natali \& Ferrannini, 2006). Although it has little impact on the absorption of glucose in the gastrointestinal tract, it can delay the absorption of glucose (Czyzyk, Tawecki, Sadowski, Ponikowska, \& Szczepanik, 1968; Pernicova \& Korbonits, 2014).
The most significant advantage of metformin is that it does not cause hypoglycemia while reducing the blood glucose level (Nasri \& Rafieian-Kopaei, 2014). As a medicine that has been used for years, the therapeutic safety is quite high. It is indicated for use in gestational diabetes, polycystic ovarian syndrome, metabolic syndrome or prediabetes period, as well as type 2 DM (Cicero, Tartagni, \& Ertek, 2012; Hostalek, Gwilt, \& Hildemann, 2015). Metformin is used single or combined with other antidiabetes agents in the treatment of type 2 DM (Sanchez-Rangel \& Inzucchi, 2017).

Repaglinide, a derivative of carbamoylbenzoic acid, enhances insulin secretion from pancreatic $\beta$-cells by closing ATP-sensitive potassium (KATP) channels in the plasma membrane (Johansen \& Birkeland, 2007; Scott, 2012). It has a short duration of action (Abbink, van der Wal, Sweep, Smits, \& Tack, 2004). It can be used primarily in type 2 DM patients with renal insufficiency since the kidneys do not perform its metabolism and elimination (Hasslacher, 2003). There are also studies showing that pharmacokinetic data in individuals with renal impairment can be safely used by kidney patients, although some studies have demonstrated minor differences to healthy individuals (Marbury, 2000; Schumacher et al., 2001; Scott, 2012).

The combined therapy of type 2 DM with repaglinide and metformin was approved in the USA in 1997 and in Europe in 1998. Since repaglinide, which provides insulin secretion, has a short-term effect, when used with metformin, the secreted insulin has the highest possible effect. Also, the fact that this combination does not have a negative effect on hepatic $\beta$-cells provides safe control of hyperglycemia for a long time (Kawamori et al., 2014).

In this study, stable fixed-dose combinations of Repaglinide and Metformin $\mathrm{HCl}$ with rapid drug release profiles were developed.

\section{MATERIALS AND METHODS}

\section{Materials}

Repaglinide (Polpharma, Poland), Metformin $\mathrm{HCl}$ (Aarti Drugs Limited, India), Povidone (PVP K25) (BASF), Microcrystalline Cellulose Types 101 and 102 (Vivapur 101 and Vivapur 102) (JRS Pharma), Sorbitol (Roquette), Polyethylene Glycol 6000 (Magrogol 6000) (Clariant), Poloxamer 188 (BASF), Meglumin (Merck), Polacriline potassium (Amberlite IRP88) (DOW), Ethanol (JT Baker), Magnesium stearate (FACI SpA), Opadry Pink 03B240027 (Colorcon). All other chemicals were analytical grade.

\section{Methods \\ Active ingredients and excipients compatibility studies}

Excipients that are included in the composition of repaglinide / metformin $\mathrm{HCl} 2$ mg / 500 mg film tablet are defined in international pharmacopoeias. Also, in the literature for the reference product PrandiMet (repaglinide/metformin $\mathrm{HCl}$ ) Tablet 2 mg / 500 mg, the excipients found in the content of the product were identified and mostly the same excipients were used in the developed formulation. To decide the 
appropriate excipients compatibility tests were performed. The samples were stored for 30 days at different ratios and in different environments $\left(2-8^{\circ} \mathrm{C}, 25^{\circ} \mathrm{C} \pm 2^{\circ} \mathrm{C} ; 60 \% \pm 5 \% \mathrm{RH}\right.$ and $\left.40^{\circ} \mathrm{C} \pm 2{ }^{\circ} \mathrm{C} ; 75 \% \pm 5 \% \mathrm{RH}\right)$ and their compatibilities were examined after 30 days. DSC thermal analysis methodology was used to evaluate the compatibility. The tests were performed by using approximately $5 \mathrm{mg}$ sample in a hermetic aluminum sample holder and heated from $35^{\circ} \mathrm{C}$ to $350^{\circ} \mathrm{C}$ at a heating rate of $10^{\circ} \mathrm{C} / \mathrm{min}$, an empty pan was used as the reference, the details of the studies are given in Table 1.

\section{Preformulation studies}

Preformulation studies were carried out to determine the quantitative composition of the formulation of the film tablets to be prepared. As a result of these studies, the physical parameters of the core tablets (hardness, disintegration, friability) were evaluated and film coating of the formulations closest to the physical parameters of the reference product was prepared, and the dissolution tests of this formulations were performed and compared with the reference product.

Table 1. Active ingredients and excipients compatibility studies details.

\begin{tabular}{|c|c|c|c|c|c|c|c|}
\hline \multirow[t]{2}{*}{ No } & \multirow[t]{2}{*}{ Mixture } & \multirow[t]{2}{*}{$\begin{array}{l}\text { Mixture } \\
\text { ratio }\end{array}$} & \multirow{2}{*}{$\begin{array}{c}2-8^{\circ} \mathrm{C} \\
30 \text { day } \\
{ }^{*} \mathrm{P}\end{array}$} & \multicolumn{2}{|c|}{$\begin{array}{l}25^{\circ} \mathrm{C} \pm 2{ }^{\circ} \mathrm{C} \\
60 \% \pm 5 \% \mathrm{RH} \\
30 \text { day }\end{array}$} & \multicolumn{2}{|c|}{$\begin{array}{c}40^{\circ} \mathrm{C} \pm 2^{\circ} \mathrm{C} \\
75 \% \pm 5 \% \mathrm{RH} \\
30 \text { day }\end{array}$} \\
\hline & & & & *P & **UP & *P & **UP \\
\hline 1 & Metformin $\mathrm{HCl}$ & - & + & + & + & + & + \\
\hline 2 & Repaglinide & - & + & + & + & + & + \\
\hline 3 & Metformin $\mathrm{HCl}+$ Repaglinide & $20: 1$ & + & + & + & + & + \\
\hline 4 & $\begin{array}{l}\text { (Metformin HCl+ Repa- } \\
\text { glinide)***+ PVP K25 }\end{array}$ & $10: 1$ & + & + & + & + & + \\
\hline 5 & $\begin{array}{l}\text { (Metformin } \mathrm{HCl+} \\
\text { Repaglinide) } \\
{ }^{* * *}+\text { Poloxamer } 188\end{array}$ & $20: 1$ & + & + & + & + & + \\
\hline 6 & $\begin{array}{l}\text { (Metformin HCl+ Repa- } \\
\text { glinide) }{ }^{\star \star *}+\text { Meglumin }\end{array}$ & $20: 1$ & + & + & + & + & + \\
\hline 7 & $\begin{array}{l}\text { (Metformin } \mathrm{HCl}+\text { Repa- } \\
\text { glinide) }{ }^{\star \star *}+\text { MCC tip } 101\end{array}$ & $5: 1$ & + & + & + & + & + \\
\hline 8 & $\begin{array}{l}\text { (Metformin } \mathrm{HCl}+\text { Repa- } \\
\text { glinide)***+ Sorbitol }\end{array}$ & $10: 1$ & + & + & + & + & + \\
\hline 9 & $\begin{array}{l}\text { (Metformin HCl+ Repa- } \\
\text { glinide) })^{\star \star *}+\text { Magrogol } 6000\end{array}$ & $20: 1$ & + & + & + & + & + \\
\hline 10 & $\begin{array}{l}\text { (Metformin } \mathrm{HCl}+\text { Repa- } \\
\text { glinide) }{ }^{* *}+\text { Polakrilin pota- } \\
\text { syum (Amberlite IRP88) }\end{array}$ & $10: 1$ & + & + & + & + & + \\
\hline 11 & $\begin{array}{l}\text { (Metformin HCl+ Repa- } \\
\text { glinide) })^{\star \star *}+\text { Akdisol }\end{array}$ & $10: 1$ & + & + & + & + & + \\
\hline 12 & $\begin{array}{l}\text { (Metformin HCl+ Repa- } \\
\text { glinide)***+ Starch } 1500\end{array}$ & $10: 1$ & + & + & + & + & + \\
\hline 13 & $\begin{array}{l}\text { (Metformin } \mathrm{HCl}+\text { Repa- } \\
\text { glinide) }^{\star \star *}+\text { Magnezyum stearat }\end{array}$ & $20: 1$ & + & + & + & + & + \\
\hline 14 & $\begin{array}{l}\text { (Metformin } \mathrm{HCl}+\mathrm{Re}^{-} \\
\text {paglinide)***+ Opadry II } \\
85 \mathrm{~F} 240049 \text { Pink }\end{array}$ & $20: 1$ & + & + & + & + & + \\
\hline 15 & $\begin{array}{l}\text { (Metformin } \mathrm{HCl}+\mathrm{Re}^{-} \\
\text {paglinide)***+ Opadry II } \\
\text { 85F220124 Yellow }\end{array}$ & $20: 1$ & + & + & + & + & + \\
\hline 16 & $\begin{array}{l}\text { (Metformin } \mathrm{HCl}+\text { Repa- } \\
\text { glinide) }{ }^{\star * *}+\text { Opadry 03B240027 } \\
\text { Pink }\end{array}$ & $20: 1$ & + & + & + & + & + \\
\hline 17 & $\begin{array}{l}\text { (Metformin } \mathrm{HCl}+\text { Repa- } \\
\text { glinid)***+ Opadry 03B220042 } \\
\text { Yellow }\end{array}$ & $20: 1$ & + & + & + & + & + \\
\hline
\end{tabular}




\section{Pilot scale batch production}

Pilot productions were prepared by using the wet granulation method. Firstly, Repaglinide granule mixture and Metformin $\mathrm{HCl}$ granule mixture were prepared and dried in the oven at $50^{\circ} \mathrm{C}$ until to obtain well-dried granules to a loss of drying value is less than $2 \%$. Dried granules were blended with external granular phase excipients. Three series of pilot production was carried out by using the unit formula and the production method determined based on the results of the in vitro dissolution test performed at zero time and after waiting for one month at $40^{\circ} \mathrm{C} \pm 2{ }^{\circ} \mathrm{C} ; 75 \% \pm 5 \% \mathrm{RH}$ of the pre-formulation studies.

The tablet serial size prepared for pilot production was 100,000 and serial numbers were P001, P002 and P0003, respectively.

\section{Physicochemical properties and dissolution tests}

Physical tests (weight variation, hardness, diameter, thickness, water content), assay, content uniformity and dissolution tests were performed on the tablets prepared in the preformulation studies on the tablets in the pilot product series.

Tablet weight variation tests were performed according to the EP 6 section 2.9.5. Uniformity of Mass of Single-Dose (European Pharmacopeia, 2008). Tweenty tablets were taken and weighed individually using digital analytical balance (Sartorius BP 3105, Germany). The results were recorded.

Tablet hardness test was performed by using Erweka hardness test equipment (D63150, Germany). 10 tablets were tested and the avarage hardness value (N) was recorded.

Disintegration test was performed according to USP <701> Disintegration test (2019). 6 tablets were checked (Erweka ZT304, Germany) and their disinteration times (min.) were recorded.

Friability \% test was performed using Erweka TAR 220 (Germany) friability tester in accordance with USP <1216> Tablet Friability (2019). Weight loss \% was calculated.

The analysis of Metformin $\mathrm{HCl}$ and Repaglinide were performed by using different system. To analyse Metformin $\mathrm{HCl}$, $\mathrm{HPLC}$ system was used and the system was operated at $40^{\circ} \mathrm{C}$ at a flow rate of $1 \mathrm{~mL} / \mathrm{min}$ and $240 \mathrm{~nm}$. The injection volume was $10 \mu \mathrm{L}$. To analyse Repaglinide, UPLC system was used and the system was operated at $25^{\circ} \mathrm{C}$ at a flow rate of $0.3 \mathrm{~mL} / \mathrm{min}$ and $240 \mathrm{~nm}$. The injection volume was $10 \mu \mathrm{L}$.

The Repaglinide/Metformine $\mathrm{HCl}$ tablet dissolution test method was performed according to the FDA dissolution method (FDA, 2009). USP apparatus II with the paddle method was used at $37^{\circ} \mathrm{C} \pm 0.5$ at $50 \mathrm{rpm}$ and the medium was $\mathrm{pH} 5.0$ citric $\mathrm{acid} /$ phosphate buffer. The samples were taken from the dissolution medium at the determined time intervals 5, 10, 15, 20, 30, 45 and 60 minutes.

The dissolution rate test was performed on the film tablets obtained as a result of pilot productions and the reference tablet (PrandiMet Tablets 2 mg / 500 mg) in the pH 5.0 citric acid/ phosphate buffer. In vitro dissolution tests were performed to the pilot production series and to the reference product at three different pHs $(1.2,4.5$ and 6.8) of the gastrointestinal tract recommended by the EMA guidelines and $\mathrm{f} 2$ similarity factors were calculated. An f2 value greater than 50 to be taken here shows the similarity between the two formulations (EMA, 2010).

\section{Stability studies}

The prepared tablets were put in the final packing and kept for stability studies. The stability studies were carried out in accordance with the storage conditions specified in the ICH Q1A (R2) guide of the three pilot production series produced. According to the ICH Q1A (R2) (2003) guidelines (ICH, 2003), longterm stability operating conditions are $25^{\circ} \mathrm{C} \pm 2^{\circ} \mathrm{C} / 60 \% \pm 5 \% \mathrm{RH}$ and accelerated stability conditions are $40^{\circ} \mathrm{C} \pm 2^{\circ} \mathrm{C} / 75 \% \pm 5 \%$ $\mathrm{RH}$. During stability, at different time intervals, the tablets were tested for its physicochemical parameters which include appearance, weight average, hardness, assay, dissolution and impurities.

\section{RESULTS AND DISCUSSION}

\section{Active ingredients and excipients compatibility test re- sults}

It was seen that all the samples in different storage conditions $\left(2-8^{\circ} \mathrm{C}, 25^{\circ} \mathrm{C} \pm 2^{\circ} \mathrm{C} ; 60 \% \pm 5 \% \mathrm{RH}\right.$ and $\left.40^{\circ} \mathrm{C} \pm 2^{\circ} \mathrm{C} / 75 \% \pm 5 \% \mathrm{RH}\right)$ of the mixtures prepared with all excipients were found suitable. There was any inconsistency in the graphics of the studies. The DSC graphic showing 10:1 active ingredients (Metformin $\mathrm{HCl}$ and Repaglinide) / Starch 1500 mixtures is given in Figure 1.

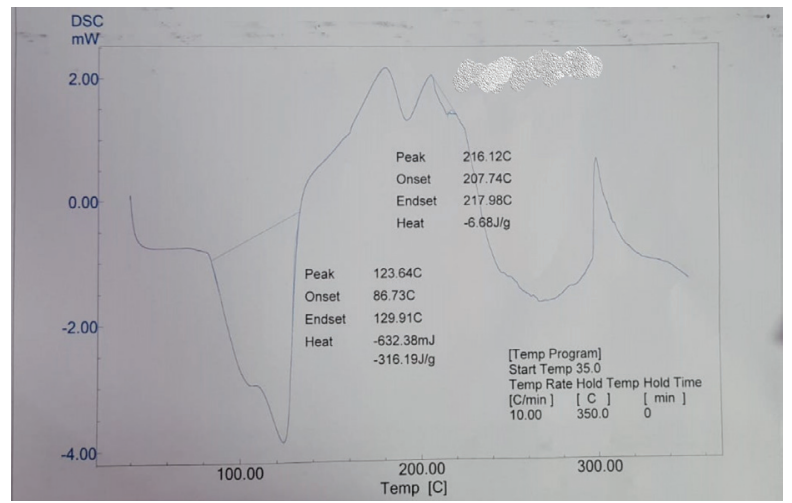

Figure 1. Active ingredients (Metformin $\mathrm{HCl}$ and Repaglinide):Starch 1500 mixture (10:1) DSC graphic under $25^{\circ} \mathrm{C} \pm 2^{\circ} \mathrm{C} / 60 \% \pm 5 \% \mathrm{RH}$ condition after 30 days.

\section{Preformulation studies}

Preformulation studies were performed, the Components of D001 and D002 formulations and the detected quantitative amounts are given in Tables 2 and 3.

The unit formula of the optimum formula determined as a result of the tests made on the tablets obtained by the preformulation studies is given in Table 4.

\section{Physicochemical properties and dissolution tests}

Physicochemical test results of the formulations D001 and D002 prepared in the preformulation studies are given in the 
Table 2. Unit formula of Repaglinide / Metformin HCl 2 mg / 500 mg film tablets coded D001.

\begin{tabular}{|lc|}
\hline $\begin{array}{l}\text { Active Ingredient and } \\
\text { excipients }\end{array}$ & Unit formula (mg/tablet) \\
\hline Repaglinide Granule & \\
\hline Repaglinide & 2.00 \\
Povidone (PVP K25) & 0.572 \\
Poloksamer 188 & 0.572 \\
Meglumine & 1.00 \\
Microcrystalline cellulose & 44.00 \\
101 (Vivapur 101) & \\
Deionized water & $q 5$. \\
Metformin HCl Granule & \\
\hline Metformin HCl & 500.00 \\
Povidone (PVP K25) & 20.00 \\
Sorbitol & 10.00 \\
Polyethylene glycol & 5.00 \\
(Magrogol 6000) & \\
Deionized water & $q 5$. \\
External Phase & \\
\hline Microcrystalline cellulose & 20.00 \\
112 (Vivapur 112) & 18.76 \\
Polacrilin potassium & \\
(Amberlite IRP88) & 3.10 \\
Magnesium stearate & 625.00 \\
Core tablet weight & 15.00 \\
Opadry 3B240027 Pink & 135.00 \\
Deionized water & 640.00 \\
Film tablet weight &
\end{tabular}

Table 3. Unit formula of Repaglinide / Metformin HCl 2 mg / 500 mg film tablets coded D002.

\begin{tabular}{|lc|}
\hline $\begin{array}{l}\text { Active Ingredient and } \\
\text { excipients }\end{array}$ & Unit formula (mg/tablet) \\
\hline Internal Phase & \\
\hline Repaglinide & 2.00 \\
Metformin HCl & 500.00 \\
Poloksamer 188 & 0.572 \\
Meglumine & 1.00 \\
Microcrystalline cellulose & 44.00 \\
101 (Vivapur 101) & \\
Povidone (PVP K25) & 20.572 \\
Sorbitol & 10.00 \\
Polyethylene glycol & 5.00 \\
(Magrogol 6000) & \\
Ethanol & qs. \\
Deionized water & $\mathrm{qs.}$ \\
External Phase & \\
\hline Microcrystalline cellulose & 20.00 \\
102 (Vivapur 112) & \\
Polacrilin potassium (Am- & 18.76 \\
berlite IRP88) & \\
Magnesium stearate & 3.10 \\
Core tablet weight & 625.00 \\
Opadry 3B240027 Pink & 15.00 \\
Deionized water & 135.00 \\
Film tablet weight & $\mathbf{6 4 0 . 0 0}$ \\
\hline
\end{tabular}

Table 4. Unit formula of the optimised formulation.

Active Ingredient and Unit formula ( $\mathrm{mg} /$ tablet)
excipients

\begin{tabular}{lc|} 
Internal Phase & \\
\hline Repaglinide & 2.00 \\
Metformin HCl & 500.00 \\
Poloksamer 188 & 0.572 \\
Meglumine & 1.00 \\
Microcrystalline cellulose & 44.00 \\
101 (Vivapur 101) & \\
Povidone (PVP K25) & 20.572 \\
Sorbitol & 10.00 \\
Polyethylene glycol & 5.00 \\
(Magrogol 6000) & \\
Ethanol & $q 5$. \\
Deionized water & $q 5$. \\
External Phase & \\
Microcrystalline cellulose & 20.00 \\
102 (Vivapur 112) & \\
Polacrilin potassium & 18.76 \\
(Amberlite IRP88) & \\
Magnesium stearate & 3.10 \\
Core tablet weight & 625.00 \\
Opadry 3B240027 Pink & 15.00 \\
Deionized water & 135.00 \\
Film tablet weight & 640.00 \\
\hline
\end{tabular}

Table 5. Physicochemical test results of formulations D001 and D002.

\begin{tabular}{|l|l|l|}
\hline Tests & D001 & D002 \\
\hline Appearance & $\begin{array}{l}\text { White or whitish } \\
\text { oblong, biconvex } \\
\text { tablet White or } \\
\text { whitish oblong, } \\
\text { biconvex tablet }\end{array}$ & $\begin{array}{l}\text { White or whitish } \\
\text { oblong, biconvex } \\
\text { tablet White or } \\
\text { whitish oblong, } \\
\text { biconvex tablet }\end{array}$ \\
$\begin{array}{l}\text { Average tablet } \\
\text { weight (mg) }\end{array}$ & 623.5 & 624.2 \\
$\begin{array}{l}\text { Hardness (N) } \\
\begin{array}{l}\text { Disintegration } \\
\text { time (min.) }\end{array}\end{array}$ & 130 & 120 \\
$\begin{array}{l}\text { Friability (\%) } \\
\begin{array}{l}\text { Loss of Water } \\
\text { Content (\%) }\end{array}\end{array}$ & 0.1 & 2 \\
\hline
\end{tabular}

Table 5. There was no significant difference in the test results obtained from the D001 and D002 formulations.

Consequently, the calibration curves used to analyze the concentration of Metformin $\mathrm{HCl}$ and Repaglinide showed good linear relationship over the concentration range 139,71 $-399,385 \mu \mathrm{g} / \mathrm{mL}$ and $1,80-8,03 \mu \mathrm{g} / \mathrm{mL}$. The correlation coefficient values were above then $>0,99$ and precise (intra- and inter-day variation $<2 \%$ ) and accurate (mean recovery $>98 \%$ ). 
The LOD and LOQ values of Metformin $\mathrm{HCl}$ were $18,67 \mu \mathrm{g} / \mathrm{mL}$ and $56.58 \mu \mathrm{g} / \mathrm{mL}$, respectively. And, The LOD and LOQ values of Repaglinide were 0,80 and $1,68 \mu \mathrm{g} / \mathrm{mL}$, respectively.

The findings of the dissolution study of pilot production tablets and commercial product in $\mathrm{pH} 5.0$ environment are given in Figure 2. At the end of 15 minutes, it was observed that both repaglinide and metformin dissolved above $85 \%$ in all formulations.
The dissolution data's of pilot production series (P001 and P002) and commercial product in different pH's 1.2, 4.5 and 6.8 are given in Figures 3, 4 and 5, respectively. As a result of dissolution studies conducted in different environments, it was observed that the active substances dissolved above 85\% after 15 minutes.

When in vitro dissolution rate test data were examined, it was determined that the amount of active substances released from
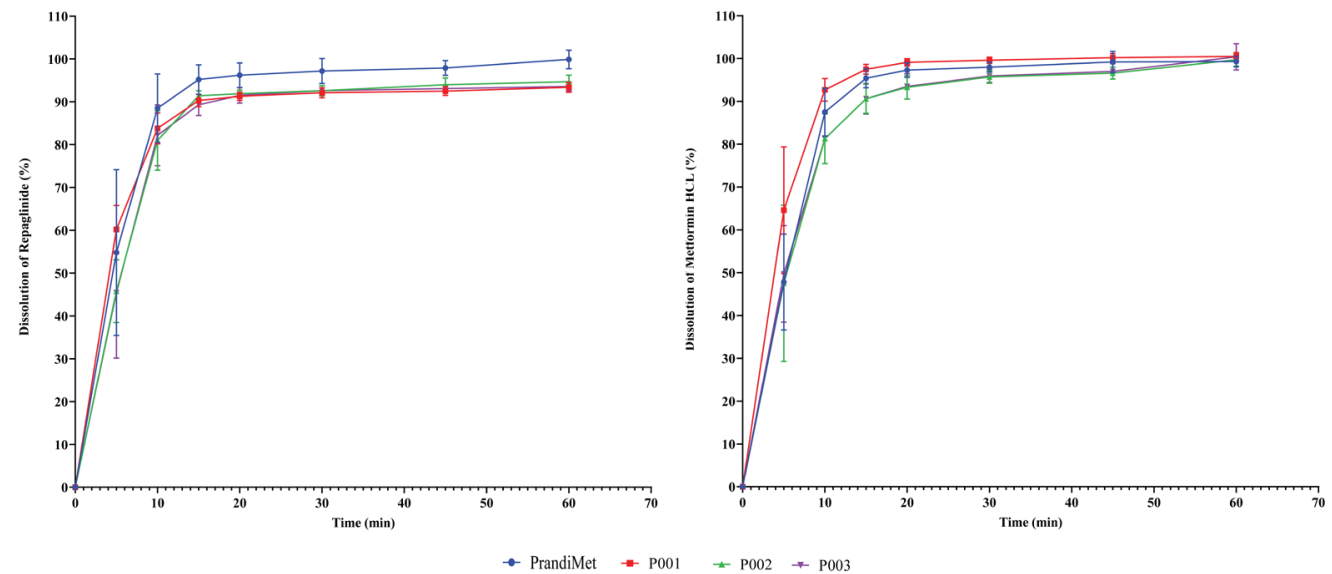

Figure 2. Pilot production formulations and the commercial product dissolution study results in $\mathrm{pH} 5.0$.
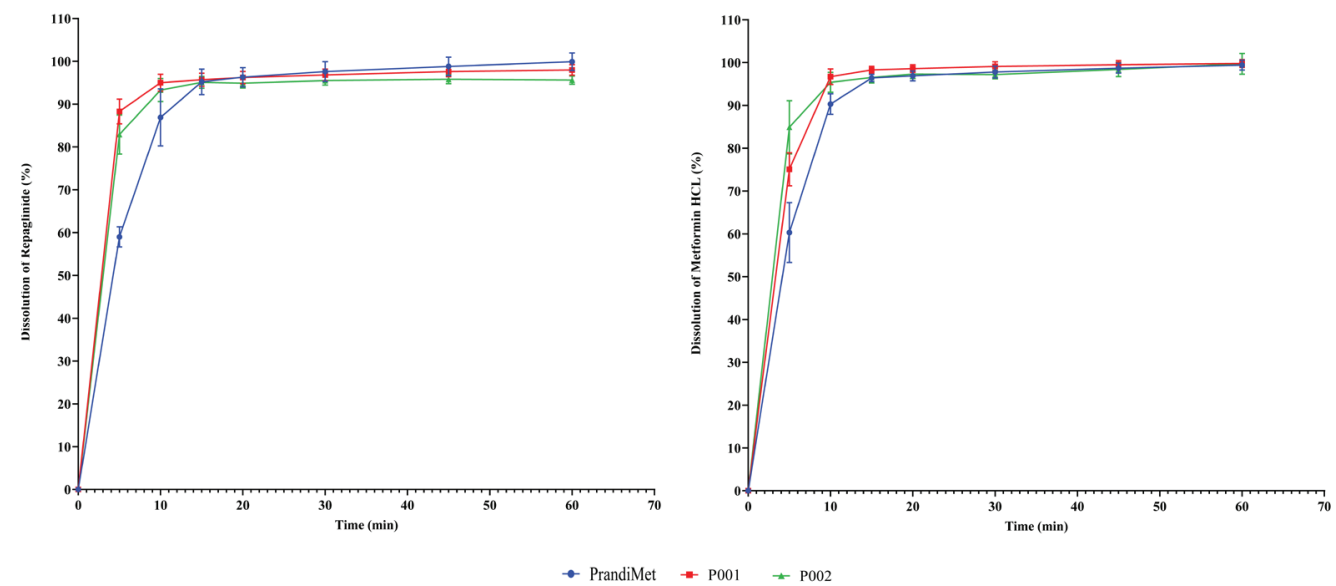

Figure 3. The dissolution profile of the commercial product and pilot production series (P001 and P002) in pH 1.2 buffer.
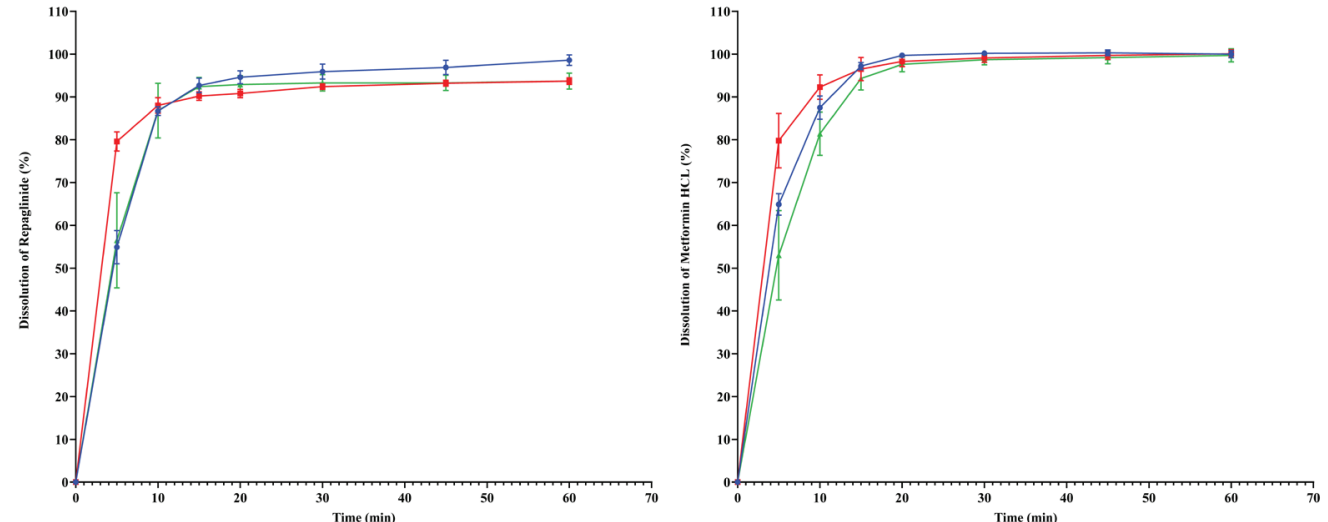

$\rightarrow$ PrandiMet $\# \mathrm{P} 001+\mathrm{P} 002$

Figure 4. The dissolution profile of the commercial product and pilot production series (P001 and P002) in pH 4.5 buffer. 


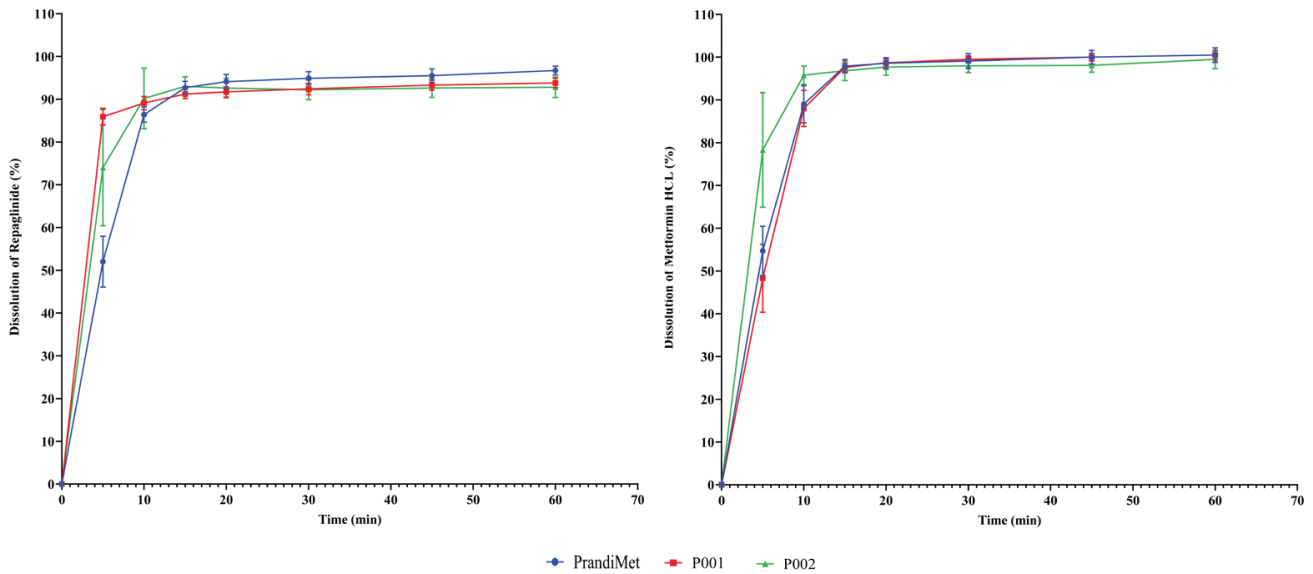

Figure 5. The dissolution profile of the commercial product and pilot production series (P001 and P002) in pH 6.8 buffer.

tablets in all 3 environments was more than $85 \%$ in 15 minutes. For this reason, it was found that they are equivalent according to EMA criteria and there is no need to perform $\mathrm{f} 2$ similarity test.

\section{Stability studies}

The stability studies are very important to provide the evidence about the quality of the tablet formulation that chang- es with time through environmental aspects. Prepared tablets were kept in stability cabines for 6 months for acceleretad stability studies $\left(40^{\circ} \mathrm{C} \pm 2^{\circ} \mathrm{C} / 75 \% \pm 5 \% \mathrm{RH}\right)$ and 24 months for long term stability studies $\left(25^{\circ} \mathrm{C} \pm 2^{\circ} \mathrm{C} / 60 \% \pm 5 \% \mathrm{RH}\right)$. The samples analyzed at the end. As a result of the findings of all physicochemical tests, assay analysis and impurity analysis, both long

Table 6. Stability test results of pilot production tablets.

\begin{tabular}{|c|c|c|c|c|}
\hline \multirow[b]{2}{*}{ Spesifications } & \multicolumn{2}{|c|}{ P001 } & \multicolumn{2}{|c|}{ P002 } \\
\hline & $\begin{array}{l}\text { Long Term* } \\
\text { (24 Month) }\end{array}$ & $\begin{array}{l}\text { Accelerated** } \\
\text { (6 Month) }\end{array}$ & $\begin{array}{l}\text { Long Term* } \\
\text { (24 Month) }\end{array}$ & $\begin{array}{l}\text { Accelerated** } \\
\text { (6 Month) }\end{array}$ \\
\hline Appereance & Suitable & Suitable & Suitable & Suitable \\
\hline $\begin{array}{l}\text { Average weight } \\
640.0 \mathrm{mg} \pm \% 5.0(608.0 \mathrm{mg}-672.0 \mathrm{mg})\end{array}$ & $638.6 \mathrm{mg}$ & $640.5 \mathrm{mg}$ & $638.3 \mathrm{mg}$ & $644.98 \mathrm{mg}$ \\
\hline $\begin{array}{l}\text { Hardness } \\
\text { (for information) }\end{array}$ & $169 \mathrm{~N}$ & $158 \mathrm{~N}$ & $167 \mathrm{~N}$ & $102 \mathrm{~N}$ \\
\hline $\begin{array}{l}\text { Disintegration } \\
\text { (max. } 30 \text { min.) }\end{array}$ & $3 \mathrm{~min}$. & $3 \mathrm{~min}$. & $3 \mathrm{~min}$. & $3 \mathrm{~min}$. \\
\hline $\begin{array}{l}\text { Water content (KF) } \\
(\text { Max. } 6 \%)\end{array}$ & $2.04 \%$ & $1.78 \%$ & $2.01 \%$ & $2.50 \%$ \\
\hline $\begin{array}{l}\text { Assay (HPLC) } \\
\text { Metformin HCl } \\
500.0 \mathrm{mg} / \mathrm{tb}(\% 90-\% 105) \\
(450.0-525.0) \mathrm{mg} / \mathrm{tb}\end{array}$ & $\begin{array}{l}497.9 \mathrm{mg} / \mathrm{tb} \\
(99.6 \%)\end{array}$ & $\begin{array}{c}486.3 \mathrm{mg} / \mathrm{tb} \\
(97.3 \%)\end{array}$ & $\begin{array}{c}497.3 \mathrm{mg} / \mathrm{tb} \\
(99.5 \%)\end{array}$ & $\begin{array}{l}488.4 \mathrm{mg} / \mathrm{tb} \\
(97.7 \%)\end{array}$ \\
\hline $\begin{array}{l}\text { Repaglinide } \\
2.00 \mathrm{mg} / \mathrm{tb}(\% 90-\% 105) \\
(1.80-2.10) \mathrm{mg} / \mathrm{tb}\end{array}$ & $\begin{array}{l}1.98 \mathrm{mg} / \mathrm{tb} \\
(99.0 \%)\end{array}$ & $\begin{array}{l}1.97 \mathrm{mg} / \mathrm{tb} \\
(98.5 \%)\end{array}$ & $\begin{array}{l}1.99 \mathrm{mg} / \mathrm{tb} \\
(99.5 \%)\end{array}$ & $\begin{array}{l}1.92 \mathrm{mg} / \mathrm{tb} \\
(96.0 \%)\end{array}$ \\
\hline $\begin{array}{l}\text { Dissolution } \\
\text { Metformin } \mathrm{HCl} \\
\text { Min } 85 \%(30 . \min )(Q=80)\end{array}$ & $98.4 \%$ & $98.5 \%$ & $95.9 \%$ & $94.3 \%$ \\
\hline $\begin{array}{l}\text { Repaglinide } \\
\text { Min } 75 \%(30 . \min )(Q=70)\end{array}$ & $92.9 \%$ & $92.2 \%$ & $92.7 \%$ & $89.0 \%$ \\
\hline $\begin{array}{l}\text { Impruties } \\
\text { Metformin } \mathrm{HCl}\end{array}$ & & & & \\
\hline $\begin{array}{l}\text { Unknown imp. \% } 0.1 \text { max. } \\
\text { Repaglinide }\end{array}$ & $0.03 \%$ & $0.01 \%$ & $0.03 \%$ & $0.03 \%$ \\
\hline Unknown imp. \% 0.2 max. & $0.06 \%$ & $0.13 \%$ & $0.08 \%$ & $0.04 \%$ \\
\hline Related imp. A \% 0.5 max. & N.D. & N.D. & N.D. & N.D. \\
\hline Related imp. C \% 0.5 max. & $0.21 \%$ & N.D. & $0.20 \%$ & $0.01 \%$ \\
\hline Total imp. \% 1.0 max. & $0.42 \%$ & $0.32 \%$ & $0.40 \%$ & $0.14 \%$ \\
\hline
\end{tabular}


and accelerated stability findings were found within the limit. The details of the analysis are given in Table 6.

\section{CONCLUSION}

The tablet formulation containing Fixed-Dose Metformin and Repaglinide was developed and compared to the commercial product available in the market. The characterization studies and the dissolution rate tests were carried out and compared with the commercial product. In dissolution studies at pH 1.2, 4.5 and 6.8 , over $85 \%$ data were obtained in 15 minutes. It was seen that it could be an alternative product to market preparation.

Peer-review: Externally peer-reviewed.

Author Contributions: Conception/Design of Study- S.Ş., Y.Ö.; Data Acquisition- S.Ş., B.M., M.E.D., E.Ö.; Data Analysis/Interpretation- S.Ş., Y.Ö., B.M., M.E.D., E.Ö.; Drafting Manuscript- S.Ş., B.M., M.E.D., E.Ö.; Critical Revision of Manuscript- S.Ş., B.M., M.E.D.; Final Approval and Accountability- S.Ş., B.M., M.E.D., E.Ö., Y.Ö.

Conflict of Interest: The authors have no conflict of interest to declare.

Financial Disclosure: Authors declared no financial support.

\section{REFERENCES}

- $\quad$ Abbink, E. J., van der Wal, P. S., Sweep, C. G. J. (Fred), Smits, P., \& Tack, C. J. (2004). Compared to glibenclamide, repaglinide treatment results in a more rapid fall in glucose level and beta-cell secretion after glucose stimulation. Diabetes/Metabolism Research and Reviews, 20(6), 466-471. https://doi.org/10.1002/dmrr.474

- American Diabetes Association. (2000). Type 2 Diabetes in children and adolescents. Pediatrics, 105(3), 671-680. https://doi. org/10.1542/peds.105.3.671

- American Diabetes Association. (2015). Classification and diagnosis of diabetes. Diabetes Care, 38(Supplement_1), S8-S16. https:// doi.org/10.2337/dc15-S005

- Cicero, A. F. G., Tartagni, E., \& Ertek, S. (2012). Mini-Special issue paper management of diabetic patients with hypoglycemic agents metformin and its clinical use: new insights for an old drug in clinical practice. Archives of Medical Science, 5, 907-917. https:// doi.org/10.5114/aoms.2012.31622

- Czyzyk, A., Tawecki, J., Sadowski, J., Ponikowska, I., \& Szczepanik, Z. (1968). Effect of biguanides on intestinal absorption of glucose. Diabetes, 17(8), 492-498. https://doi.org/10.2337/diab.17.8.492

- EMA. (2010). Guideline on the investigation of bioequivalence. Retrieved from https://www.ema.europa.eu/en/documents/ scientific-guideline/guideline-investigation-bioequivalencerev1_en.pdf

- $\quad$ European Pharmacopeia 6. <2.9.5.> Uniformity of mass of singledose preparations. Retrieved from \%2020907e.pdf

- FDA. 2009. Dissolution methods. Retrieved from https://www. accessdata.fda.gov/scripts/cder/dissolution/dsp_getalldata.cfm

- Gautam, C. S., \& Saha, L. (2008). Fixed dose drug combinations (FDCs): rational or irrational: a view point. British Journal of Clinical Pharmacology, 65(5), 795-796. https://doi.org/10.1111/j.13652125.2007.03089.x

- Godman, B., McCabe, H., \& D Leong, T. (2020). Fixed dose drug combinations - are they pharmacoeconomically sound? Findings and implications especially for lower- and middle-income countries. Expert Review of Pharmacoeconomics \& Outcomes Research, 20(1), 1-26. https://doi.org/10.1080/14737167.2020.1734456
Hasslacher, C. (2003). Safety and efficacy of repaglinide in type 2 diabetic patients with and without impaired renal function. Diabetes Care, 26(3), 886-891. https://doi.org/10.2337/diacare.26.3.886 Hostalek, U., Gwilt, M., \& Hildemann, S. (2015). Therapeutic use of metformin in prediabetes and diabetes prevention. Drugs, 75(10), 1071-1094. https://doi.org/10.1007/s40265-015-0416-8

- $\quad$ ICH. (2003). Stability testıng of new drug substances and products Q1A(R2). Retrieved from https://database.ich.org/sites/default/files/Q1A\%28R2\%29 Guideline.pdf

- Johansen, O. E., \& Birkeland, K. I. (2007). Defining the role of repaglinide in the management of type 2 diabetes mellitus. American Journal of Cardiovascular Drugs, 7(5), 319-335. https://doi. org/10.2165/00129784-200707050-00002

- $\quad$ Kawamori, R., Kaku, K., Hanafusa, T., Oikawa, T., Kageyama, S., \& Hotta, N. (2014). Effect of combination therapy with repaglinide and metformin hydrochloride on glycemic control in Japanese patients with type 2 diabetes mellitus. Journal of Diabetes Investigation, 5(1), 72-79. https://doi.org/10.1111/jdi.12121

Lefèbvre, P. J., \& Scheen, A. J. (1992). Management of non-insulindependent diabetes mellitus. Drugs, 44(Supplement 3), 29-38. https://doi.org/10.2165/00003495-199200443-00005

- L Longo, M., Bellastella, G., Maiorino, M. I., Meier, J. J., Esposito, K., \& Giugliano, D. (2019). Diabetes and aging: From treatment goals to pharmacologic therapy. Frontiers in Endocrinology, 10. https://doi. org/10.3389/fendo.2019.00045

- Maffi, P., \& Secchi, A. (2017). The Burden of Diabetes: Emerging Data. https://doi.org/10.1159/000459641

- Malone, J. I. (2016). Diabetic central neuropathy: CNS damage related to hyperglycemia. Diabetes, 65(2), 355-357. https://doi. org/10.2337/dbi15-0034

Marbury, T. (2000). Pharmacokinetics of repaglinide in subjects with renal impairment. Clinical Pharmacology \& Therapeutics, 67(1), 7-15. https://doi.org/10.1067/mcp.2000.103973

- Massi-Benedetti, M., \& Orsini-Federici, M. (2008). Treatment of type 2 diabetes with combined therapy: What are the pros and cons? Diabetes Care, 31 (Supplement 2), S131-S135. https://doi. org/10.2337/dc08-s233

- $\quad$ Nasri, H., \& Rafieian-Kopaei, M. (2014). Metformin: Current knowledge. J Res Med Sci, 19(7), 658-664.

Natali, A., \& Ferrannini, E. (2006). Effects of metformin and thiazolidinediones on suppression of hepatic glucose production and stimulation of glucose uptake in type 2 diabetes: a systematic review. Diabetologia, 49(3), 434-441. https://doi.org/10.1007/ s00125-006-0141-7

Pernicova, I., \& Korbonits, M. (2014). Metformin—mode of action and clinical implications for diabetes and cancer. Nature Reviews Endocrinology, 10(3), 143-156. https://doi.org/10.1038/ nrendo.2013.256

Rachdaoui, N. (2020). Insulin: The friend and the foe in the development of type 2 diabetes mellitus. International Journal of Molecular Sciences, 21(5), 1770. https://doi.org/10.3390/ijms21051770 Riddle, M. C., \& Herman, W. H. (2018). The cost of diabetes careAn elephant in the room. Diabetes Care, 41(5), 929-932. https:// doi.org/10.2337/dci18-0012

- $\quad$ Sanchez-Rangel, E., \& Inzucchi, S. E. (2017). Metformin: clinical use in type 2 diabetes. Diabetologia, 60(9), 1586-1593. https://doi. org/10.1007/s00125-017-4336-x

Schumacher, S., Abbasi, I., Weise, D., Hatorp, V., Sattler, K., Sieber, J., \& Hasslacher, C. (2001). Single- and multiple-dose pharmacokinetics of repaglinide in patients with type 2 diabetes and renal impairment. European Journal of Clinical Pharmacology, 57(2), 147-152. https://doi.org/10.1007/s002280100280

Scott, L. J. (2012). Repaglinide. Drugs, 72(2), 249-272. https://doi. org/10.2165/11207600-000000000-00000 
Istanbul J Pharm 51 (1): 26-34

- $\quad$ Spampinato, S. F., Caruso, G. I., De Pasquale, R., Sortino, M. A., \& Merlo, S. (2020). The treatment of impaired wound healing in diabetes: Looking among old drugs. Pharmaceuticals, 13(4), 60. https://doi.org/10.3390/ph13040060

- Tangalos, E. G., \& Zarowitz, B. J. (2005). Combination drug therapy. Journal of the American Medical Directors Association, 6(6), 406409. https://doi.org/10.1016/j.jamda.2005.04.013

- The United States Pharmacopeia (USP), <701> Disintegration, 2019. Retrieved from https://www.usp.org/sites/default/ files/usp/document/harmonization/gen-method/q02_pf_ ira_31_2_2005.pdf

- The United States Pharmacopeia (USP), <1216> Tablet Friability, 2019. Retrieved from https://www.usp.org/sites/default/ files/usp/document/harmonization/gen-chapter/g06_pf_ ira_32_2_2006.pdf
- $\quad$ Tsioufis, C., \& Thomopoulos, C. (2017). Combination drug treatment in hypertension. Pharmacological Research, 125, 266-271. https://doi.org/10.1016/j.phrs.2017.09.011

- World Health Organization. 2020. Diabetes. Retrieved from https://www.who.int/news-room/fact-sheets/detail/diabetes

Young-Hyman, D., de Groot, M., Hill-Briggs, F., Gonzalez, J. S., Hood, K., \& Peyrot, M. (2016). Psychosocial care for people with diabetes: A position statement of the American Diabetes Association. Diabetes Care, 39(12), 2126-2140. https://doi.org/10.2337/dc16-2053 